
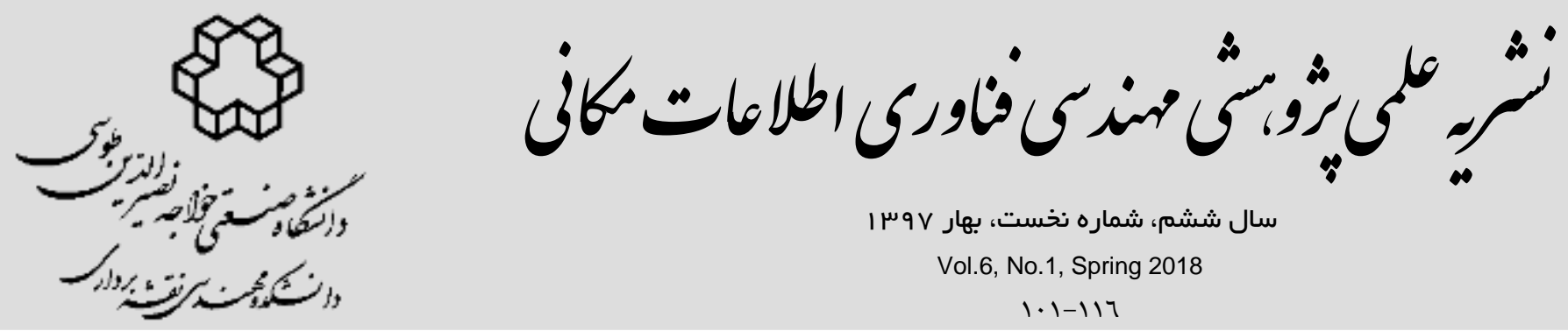

I س

Vol.6, No.1, Spring 2018

$1.1-117$

\author{
بهبود آشكارسازى تغييرات كاربرى اراضى با استفاده از روش هسته مبناى \\ نغارنده زاويه طيفى در تصاوير فراطيفى لئى \\ مهدى حسنلو"*! سيد تيمور سيدى ‘، عبدالرضا سيدى؟

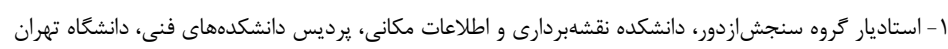

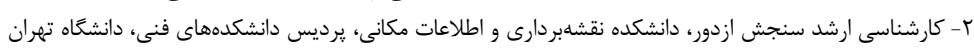

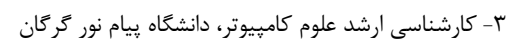

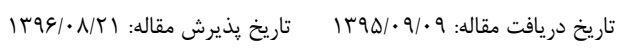

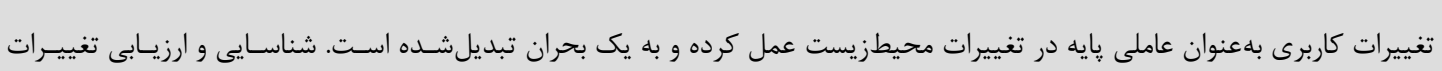

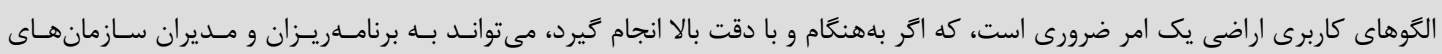

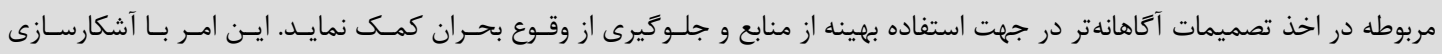

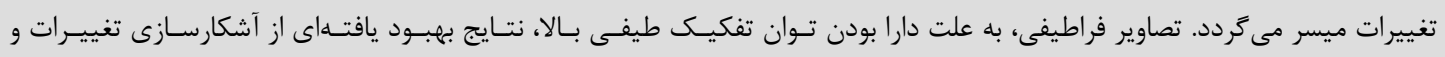

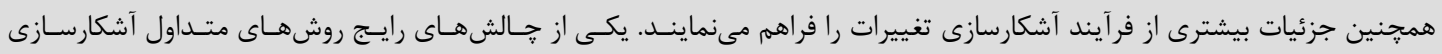

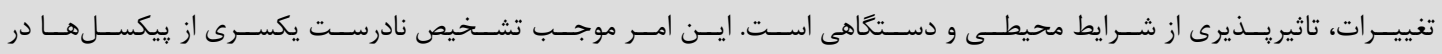

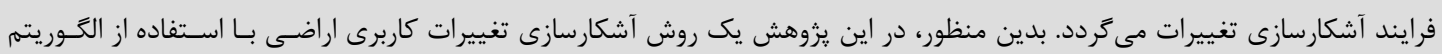

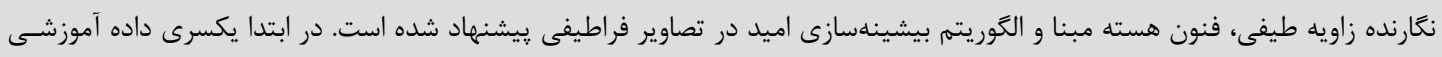

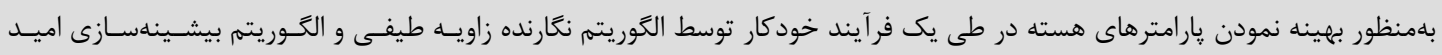

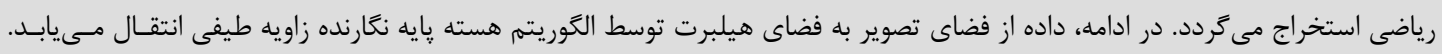

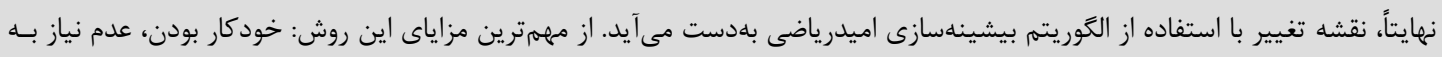

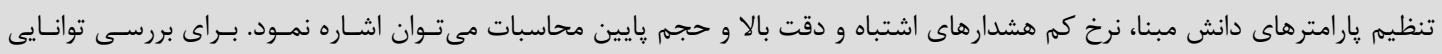

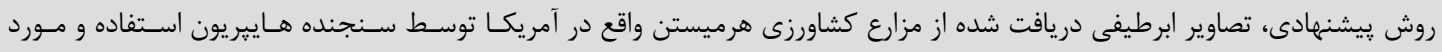

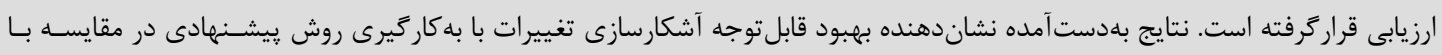

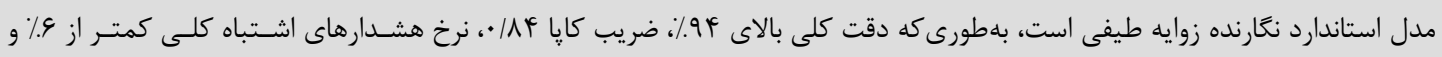

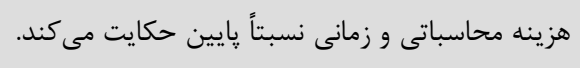

كليدوازهها: تصاوير فراطيفى، آشكارسازى تغييرات، هسته مبنا، طبقهبندى بيشينهسازى اميد، نكارنده زوايه طيفى.

ق*نويسنده مكاتبه كننده: خيابان كاركرشمالى، دانشكده مهندسى نقشهبردارى و اطلاعات مكانى، برديس دانشكدهاى فنى، دانشكاه تهران Email: hasanlou@ut.ac.ir 
فاجعه، بلروزرسانى نقشههاى تغييرات كاربرى اراضس و

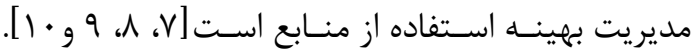

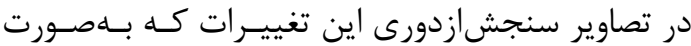

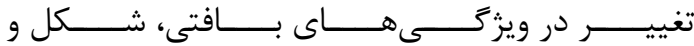

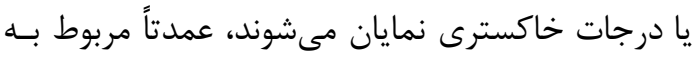

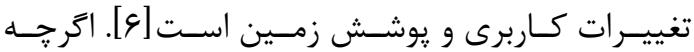
عوامل ديخـرى مانــــ؛ اثـرات اتمسـفرى، وجــود نـويز، تفاوت زاويه تابش خورشيد و اثـرات فصـلى هـم باعث باوير جندزمانـ

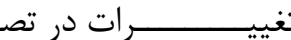

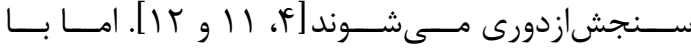
يكسرى يِيش يردازشها يا يس يردازشهايى مىتوان اثر

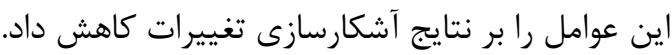
تغييرات مربوط بــه خصوصـيات بيـوفيزيكى و يوشـش اراضى از جمله تغييراتى هستند كه بهطــور مسـتقيم و غيرمستقيم بر زندكى جامعه بشرى تاثير قابـل تـوجهى إنى

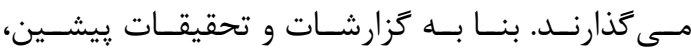
اين تغييرات تاثير زيادى بـر محسيط زيسـت، اقتصـاد و مسائل اجتماعى كذاشته اسـت. بـهـ طــور مثــال تبـديل

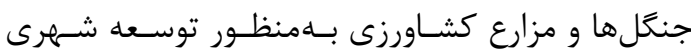
باعث شـده تـا حجـم محصـولات غـذايى بــا كيفيـت و و

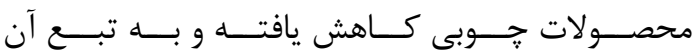

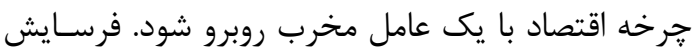
و شورى خاك، كويرزايى و سـاير مشـتقاتى نمونسهاى از اثـرات منفـى ايـن تغييـرات در عرصـه محسيط زيسـت

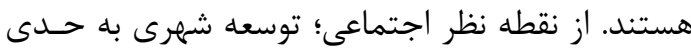

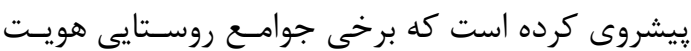

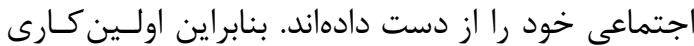

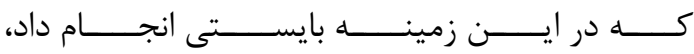

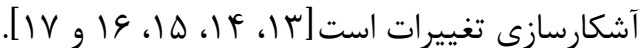
با توجه به اهميت آشكارسـازى تغييـرات در شناسـايى تغييـرات كـاربرى زمسـين و ويوشـش اراضـى لازم اسـت

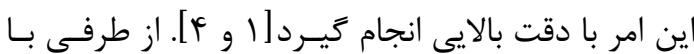
ييشرفت فن آورى امكان اخذ داده با حد تفكيك مكانى، طيفى، زمـانى و راديـومتريكى بـالا ميسـر شــده اسـت.
| - مقدمه

از زيدايش سنجشازدور تاكنون، سنجندههاى متنـوعى

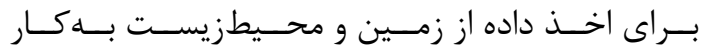

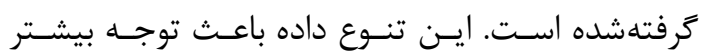
محققان به تحليل دادههاى سنجشازدورى و به تبع آن

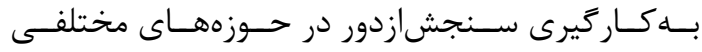
شـده اسـت. بــا ييشـرفت تكنولــوزى، امكــان ســاخت

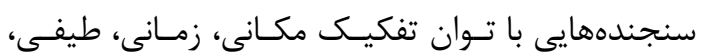

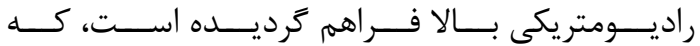

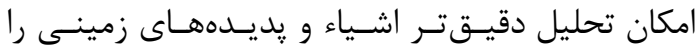

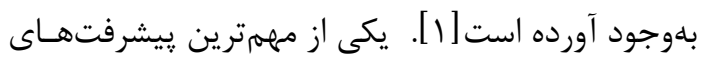

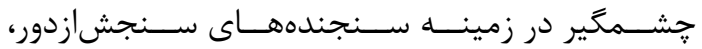
ساخت سنجندههاى فراطيفى با قابليت اخـذ تصـوير بـا توان تفكيك طيفى بالا (صدها باند طيفى با طول مـوج

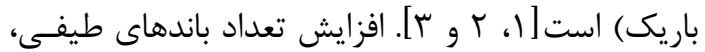
اطلاعات بيشـترى در زمينــه شناسـايى و طبقـهـنـــى

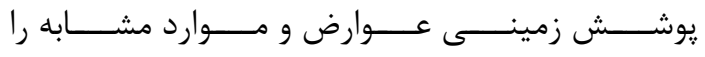

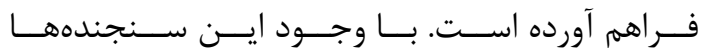

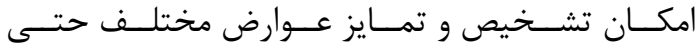

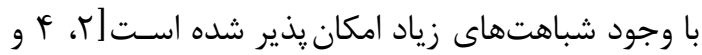
ه]. از اين رو مطالعات كستردهاى روى تصاوير فراطيفى

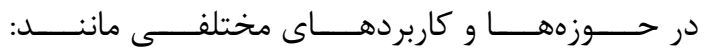
شناسايى اهـداف، طبقــهبنـدى، شناسـايى ناهنجــارى و آشكارسازى تغييرات انجام گرفته است [ه]. در اين بين يكى از كاربردهاى اصلى تصاوير فراطيفى كـهـ در زنــد

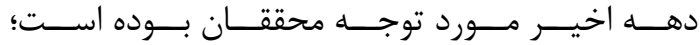
آشكارسازى تغييرات است.

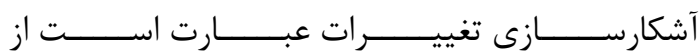
مجموعــه يــردازشهـايى كـهـ تغييـرات يـكـ شـى يـا

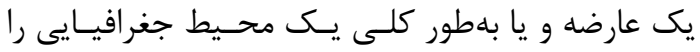

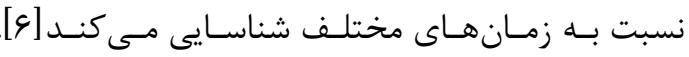

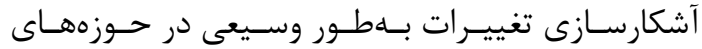
مختلف مطالعات علـوم زمــين كـاربرد دارد كـه شـامل: يايش توسعه شهرى، يايش جنگلها، جلوگيرى از وقوع 
بلهتبع آن كيفيت و كميت داده آموزشى باعث شده تا از محبوبيت اين روش كاسته شود.

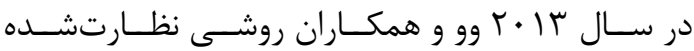

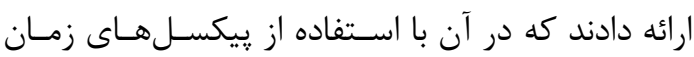

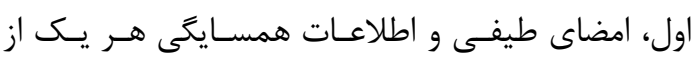

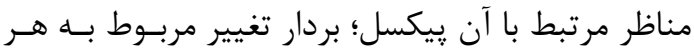

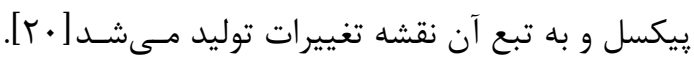

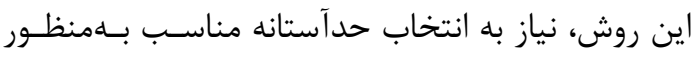

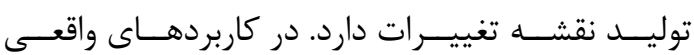

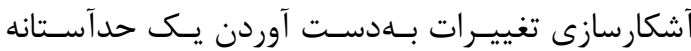

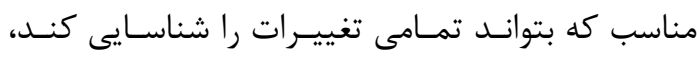
كار مشكلى اسـت. عـلاوه بــــآن تاثير يـذيرى ايــن روش در برابر شرايط دستخاهى و محيطى كاملاً مشهود است. در سال \& أ ب لو و همكاران روش مبتنى بـر الخَـوريتم

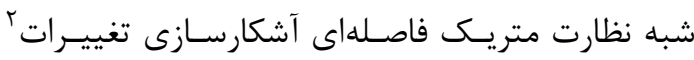

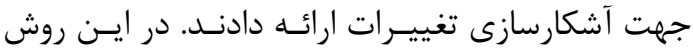

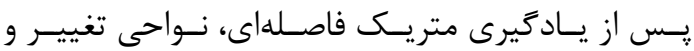

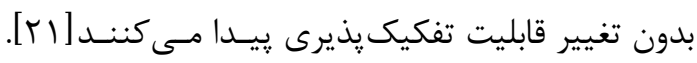

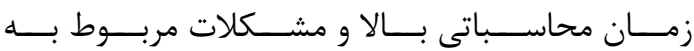
اخذ داده آموزشى بين تصاوير جندزمانه باعث شده تا از محبوبيت اين روش كاسته شود. در سال ها • ب يلازا و همكاران يـك روش آشكارسـازى

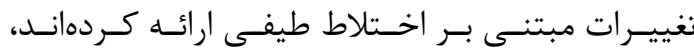

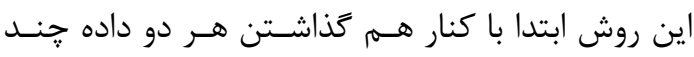

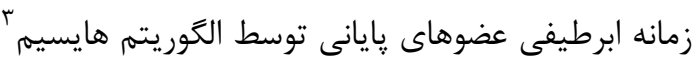

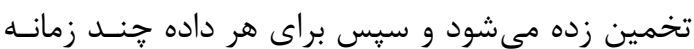

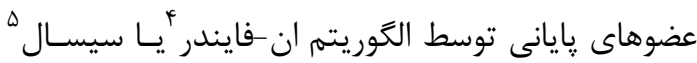

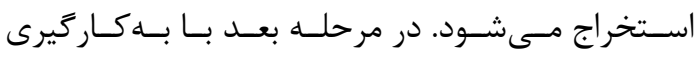

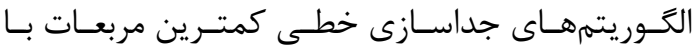

${ }^{2}$ Semi supervised Distance Metric for Change Detection (SSDM-CD)

${ }^{3}$ Hysime

${ }^{4} \mathrm{~N}$-finder

${ }^{5}$ Sisal
صحت و كيفيـت خروجى محصـولات سـنجشازدورى

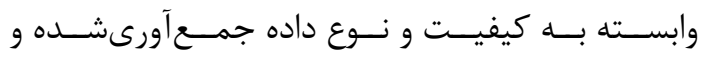

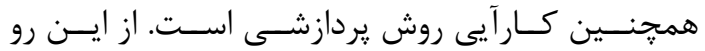

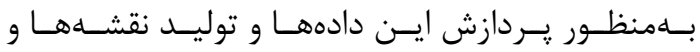
لايـهـهـاى اطلاعـات مكـانى دقيـق و بــاصـحت بــالا،

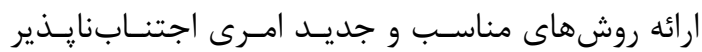

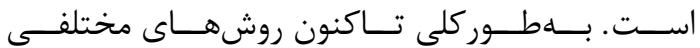

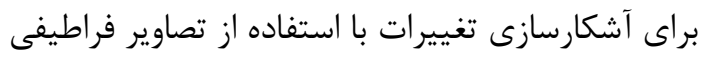

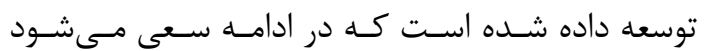
هر كدام از اين روشها بهطور خلاصه ارائه شوند

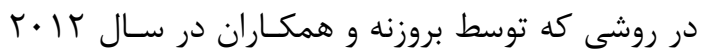

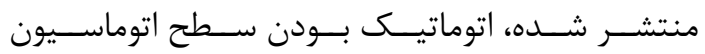

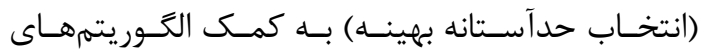

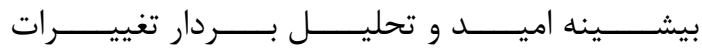

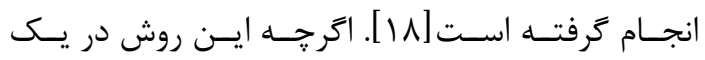

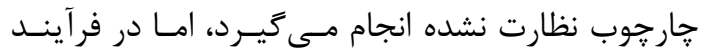
انتخاب حدآستانه به يكى هيستوكرام شـفاف نيـاز داردا

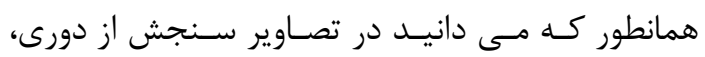

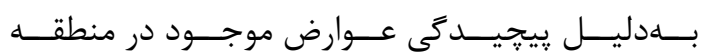

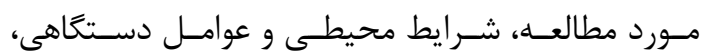

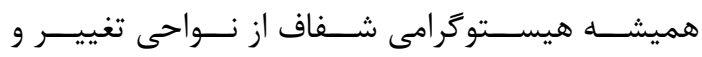
بدون تغيير وجود ندارد. اين مساله موجب عدم انتخـاب

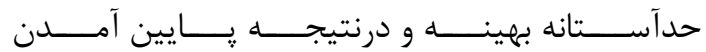
دقت آشكارسازى تغييرات مى حردد.

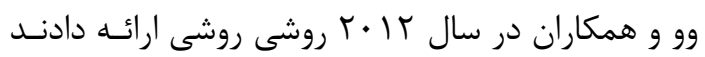

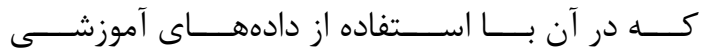

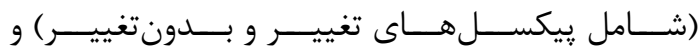

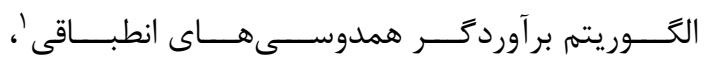
آشكارسازى تغييرات انجام مى كرفت. در اين روش براى

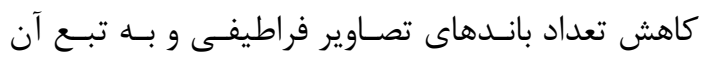

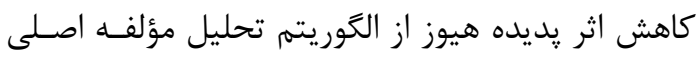

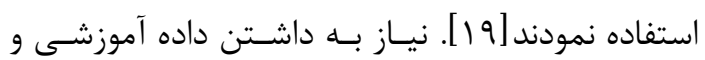

${ }^{1}$ Adaptive Coherence/Cosine Estimator (ACE) 


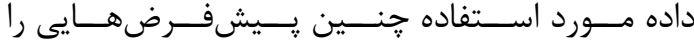
نداشته باشد، نتايج حاصل جوابكوى نيازهـاى كـاربردى

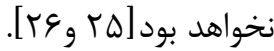
با توجه به جالشها و مشـكلات آشكارســازى تغييـرات، نياز به داشتن يك روش آشكارسازى تغييرات كه بتواند

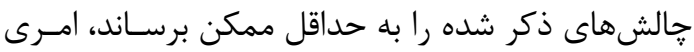

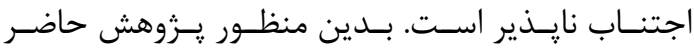
در نظر دارد، يك جارجوب جديد آشكارسازى تغييـرات را ارائه دهد كه بتواند جالشهاى موجود در آشكارسازى تغييرات را به حداقل برساند. علاوه بر آن در نظـر دارد، يتانسيل و ظرفيت نكارنده زوايه طيفى هسته مبنا را بـا

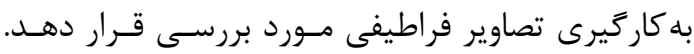
اين روش در دستهبندى روشهاى متدوال آشكارسـازى

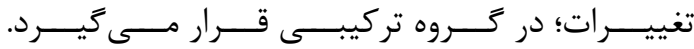

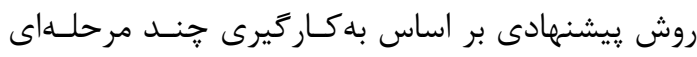

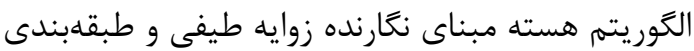

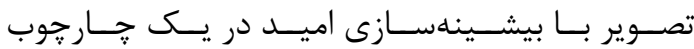
بدون نظارت انجام مىشود. در بخشهاى بعدى جزئيات

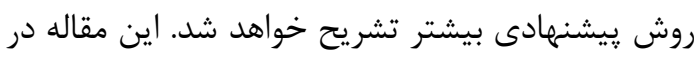

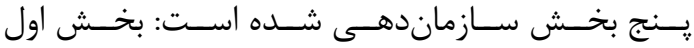

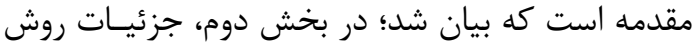

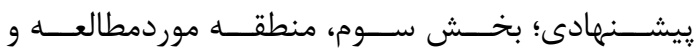
ييشيردازشها؛ بخش جهارم، ارائه نتايج و يِيادهازى و بخش ينجم، نتيجه گيرى و ارائه نتايج آمده است.

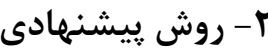

اين بخش به تشريح جزئيات سـاختار روش پيشــــــادى

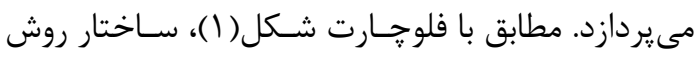

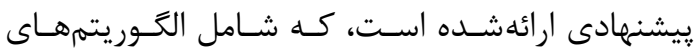
نغارنده زوايه طيفى و طبقهبندى تصوير با بيشينهسازى ارئن

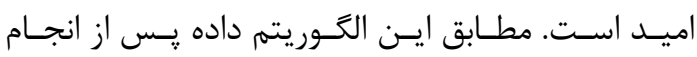

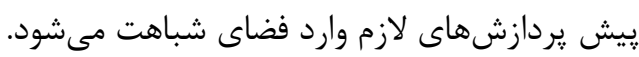

قيود كامل، بـردار فراوانسى محاسـبه و نهايتـاً اطلاعـات

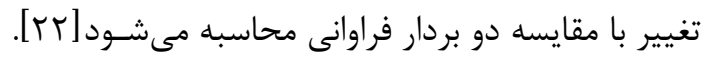

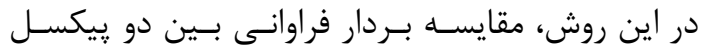

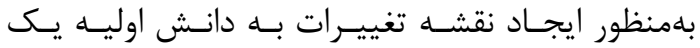

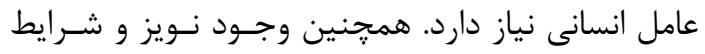

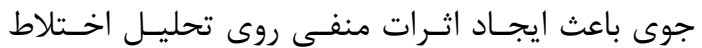

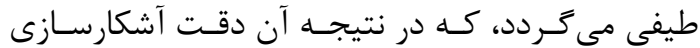
تغييرات يايين مى آيد.

بلهور كلى روشهاى آشكارسازى تغييرات را مسىتـوان

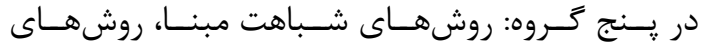

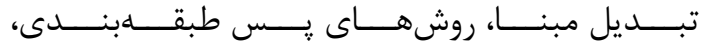

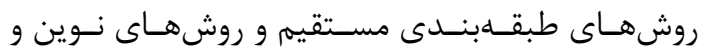

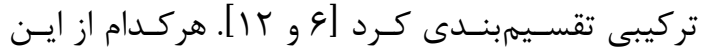
روشها داراى مزايا و معايبى است كه بسته به كاربرد و

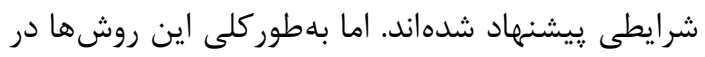
آشكارسازى تغييرات با تصاوير فراطيفى داراى معـايبى

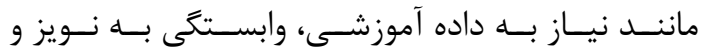

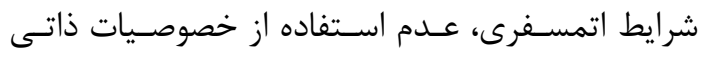

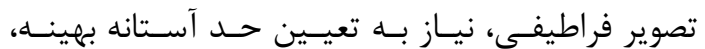
انتخاب باندهاى بهينه، حجم بالاى محاسـبات، نيـاز بــهـ

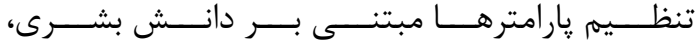

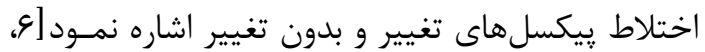

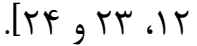
الكوريتم نتخارنـده زاويـهـ طيفـى، يكسى از متـدوالتـرين الكوريتمهاى سنجشازدورى است كه به وفور در تحليل

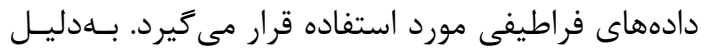

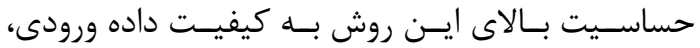

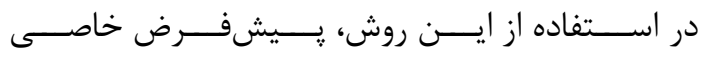

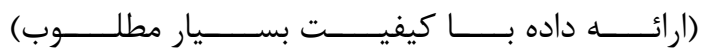

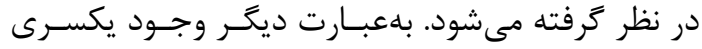

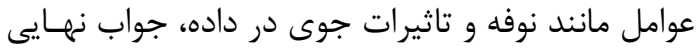

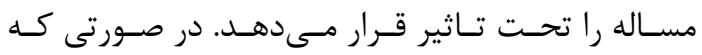



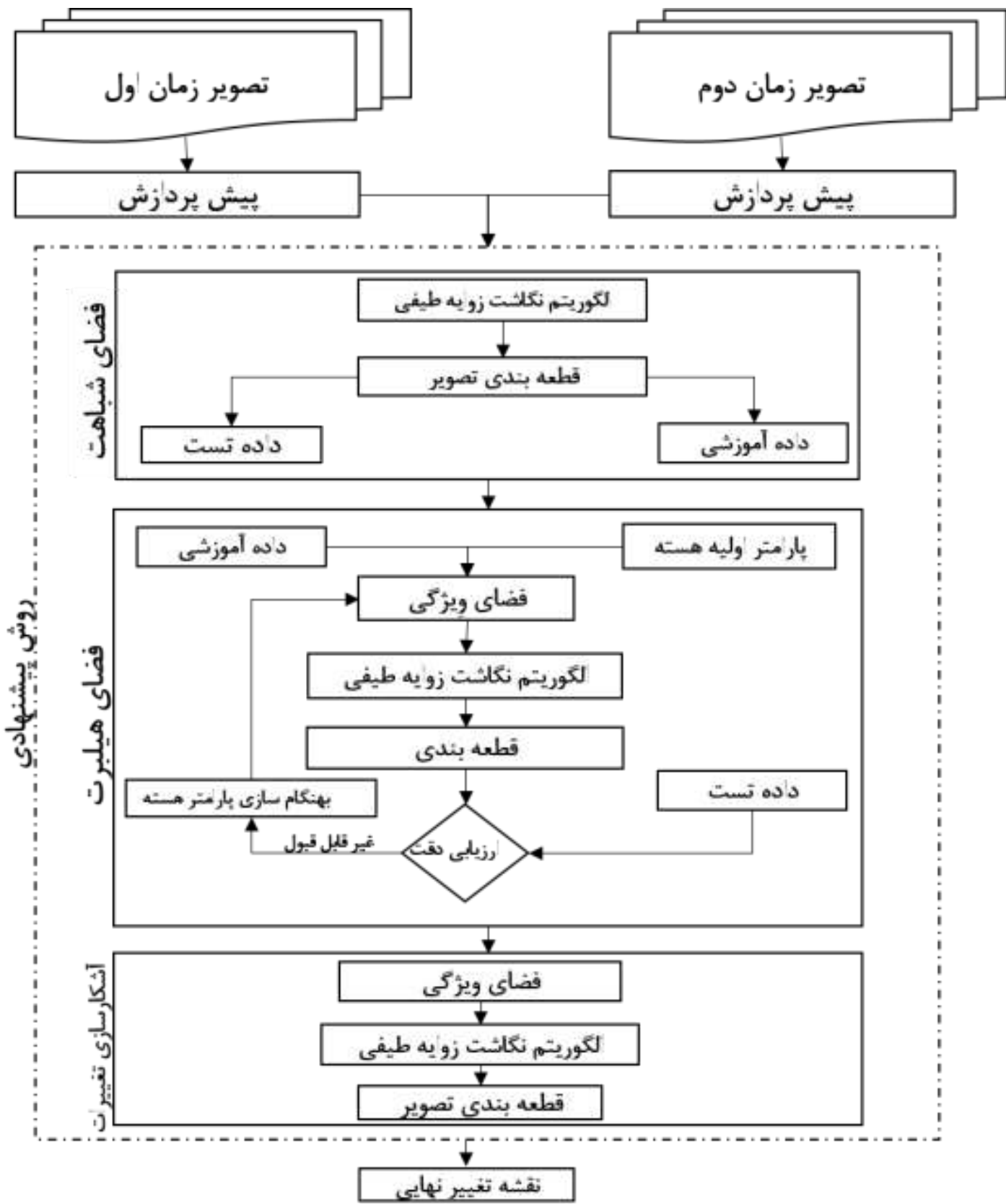

شكل ا: فلوجارت روش بيشنهادى

استخراج مىشود. اين داده آموزشى، وارد فضاى ويزگى ئى

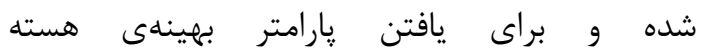
مورد ارزيابى قرار مى ميرد. مقادير بهينه يارامترهاى

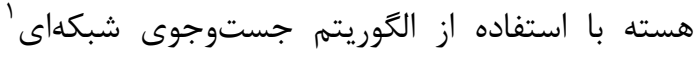

\footnotetext{
${ }^{1}$ Grid Search
}

در ابتدا، نواحى تغيير و بدون تغيير، توسط الكَوريتم

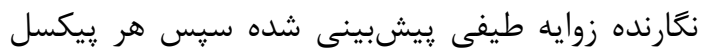
توسط الكوريتم بيشينهسازى اميد، تصميمكيرى و و

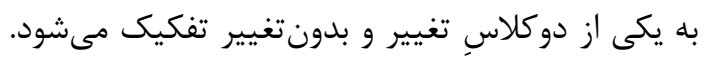

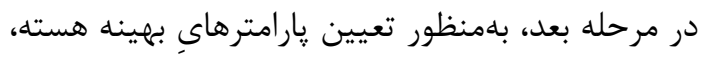

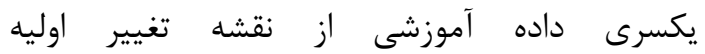




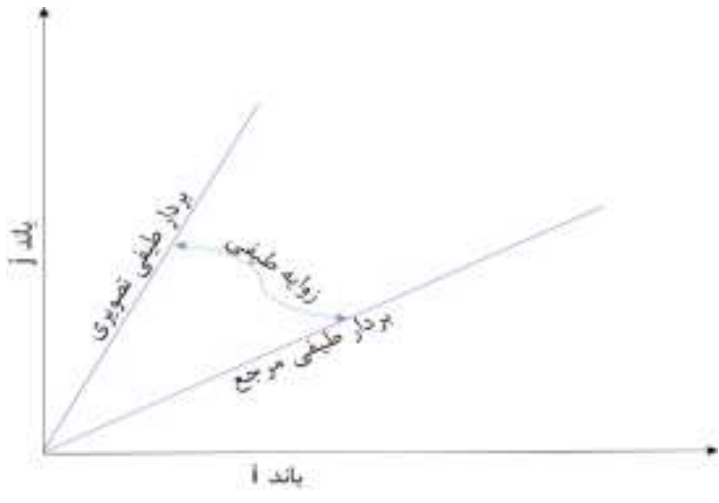

شكل r: الكَوريتم نغارنده زوايه طيفى

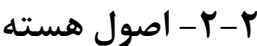

استفاده از روشهــاى هسـته مبنـا در تشـخيص الخَو و

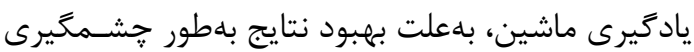

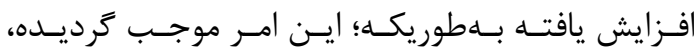
در بسـيارى از تحليـلـهـاى ســنجشازدورى از جملـه:

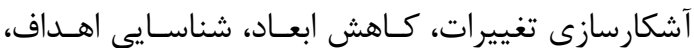
شناسايى ناهنجارى، يايش تخريب و طبقهبنـدى مـورد

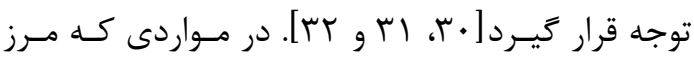
تصميمگيرى بهصورت خطى جدايذير نيست، استفاده از

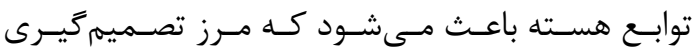

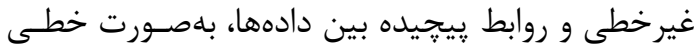

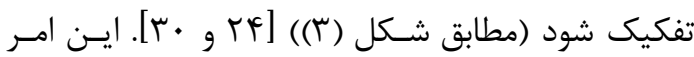
با يك نغاشت غيرخطى، با انتقال داده از فضـاى تصـوير

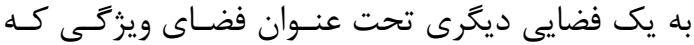
داراى ابعادى متفاوت از فضاى ورودى (فضـاى تصـوير)

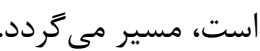

توابع هسته داراى شكلهاى مختلفى است كه مهرمترين

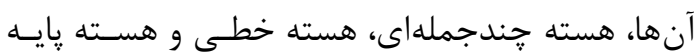

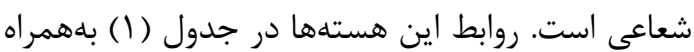
يارامترهاى آن نشان داده شده است.
تعيين مى گردد. يس از تعيين مقدار بهينه پيارامتر

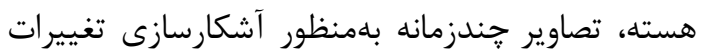
به مراحل الكوريتم پيشنهادى وارد مىشوند و نقشه تغيير نهايى توليد مىشود. در بخشهاى بعدى به تشريح جزئيات روش ييشنهادى يرداخته شده است. r-1 - الكوريته نغارنده زاويه طيفى

الكوريتم نغارنده زوايه طيفى زيرمجموعـه از روشهـاى

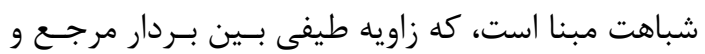

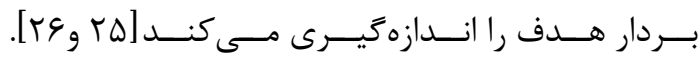

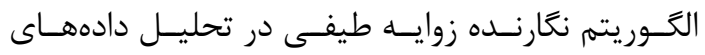

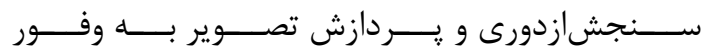
استفاده مىشود. ازجمله مهمترين اين كاربردها مىتوان

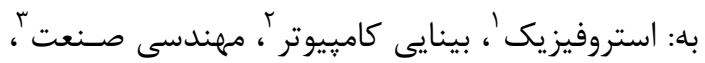

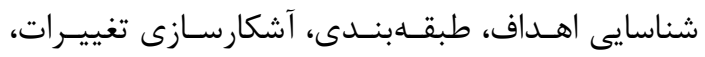
تصحيحهـاى اتمسـفرى و شـاخص ارزيـابى كيفيـت در عضو يايانى استخراج شده، فشردهسازى تصوير و حـذف

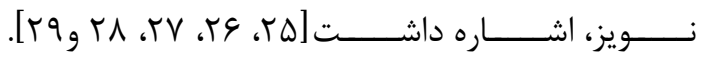
بـهعلـت مسـتقل بــودن زاويـهـ طيفـى از طــول بــردار، اين الغوريتم دربرابر تابشهــاى متفـاوت نـور خورشـيد

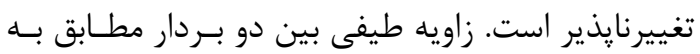
رابطه ( ) تعريف مىشود.

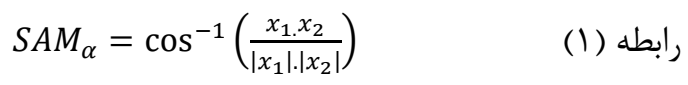

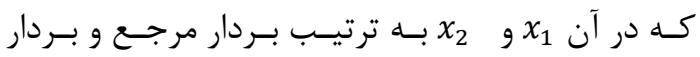
هدف اسـت. شـكل (r) زاويـه طيفـى بـين دو بـردار را نشان مى نـده.

\footnotetext{
${ }^{1}$ Astrophysics

${ }^{2}$ Computer Vision

${ }^{3}$ Industrial Engineering
} 


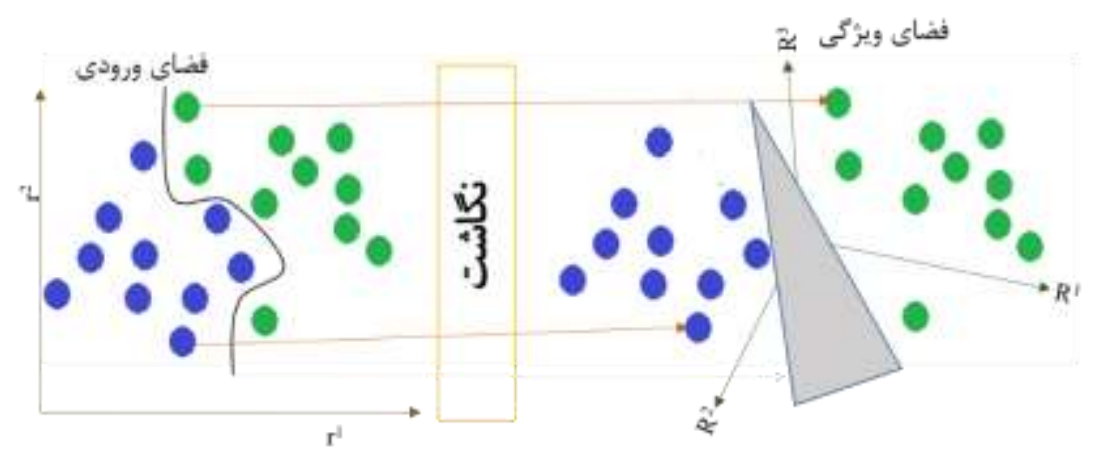

شكل r: نحوه نكَاشت داده از فضاى ورودى به فضاى ويرگى توسط هسته

جدول ا: انواع توابع هسته يֶايه و پارامترهاى تخمين

\begin{tabular}{|c|c|c|c|}
\hline نوع هسته & رابطه رياضى & يارامترهاى تخمين & تعداد يارامترها \\
\hline خطى & $k(x . y)=x^{T} y$ & . & . \\
\hline جندجملهاى & $k(x \cdot y)=\left(\gamma x^{T} y+\beta_{0}\right)^{d}$ & d. $\gamma \cdot \beta_{0}$ & $r$ \\
\hline يايه شعاعى & $k(x . y)=e^{\left(-\gamma\|x-y\|^{2}\right)}$ & $\gamma$ & 1 \\
\hline
\end{tabular}

$\varphi: X \rightarrow F, x \rightarrow \varphi(x)$

(r) (بطة

r-r- - هسته نگًارنده زاويه طيفى

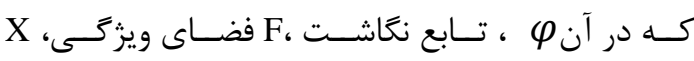

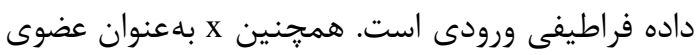

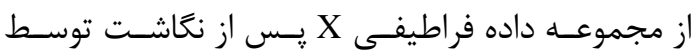

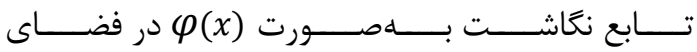

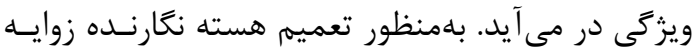

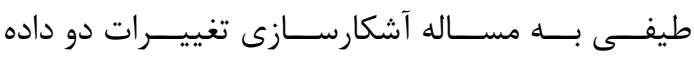

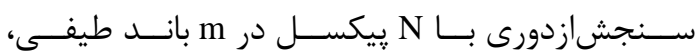
$\mathrm{U}=\left\{u_{1}, \ldots ., u_{N}\right\} \subset R^{m}, \mathrm{~V}=\left\{v_{1}, \ldots ., v_{N}\right\} \subset R^{m}$ در نظر بخيريد. اين دادهها يس از نخاشت توسط تابع

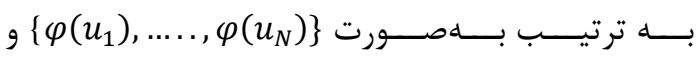
.

از آنجايى كه، رابطـهـه رياضـى تـابع نعاشـت بـه سـادگى

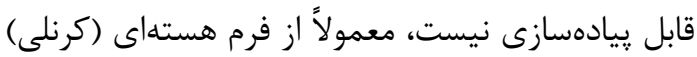

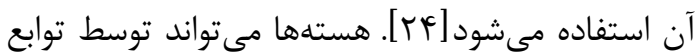
مختلفى تعريف شود، امـا رابطــه كلـى بــراى دو نمونـهـ u $u_{j}$

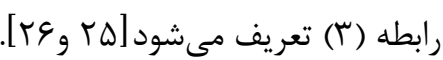
$K\left(v_{i} \cdot u_{j}\right)=\left\langle\varphi\left(v_{i}\right) \cdot \varphi\left(u_{j}\right)\right\rangle \quad$ (r)
داده ورودى، توسط تابع نگاشت به يك فضاى جديـدى،

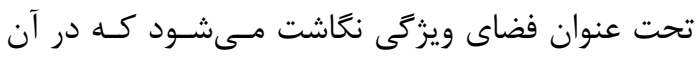

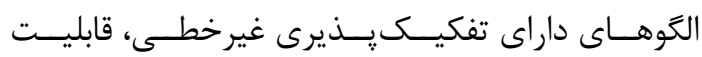
تفكيك خطى مسى يابنـد. بـهمنظــور درك بهتـر مسـاله تغيير ابعاد، شكل (؟) را در نظــر بخيريـد. فـرض كنيـد:

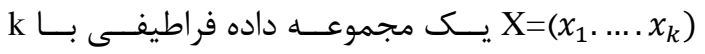

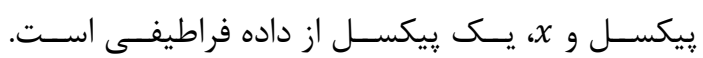

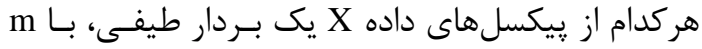

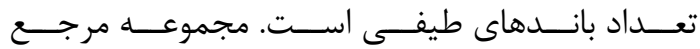

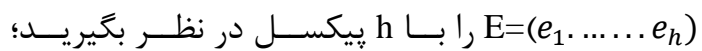
كه هركدام از ييكسلهاى آن، يك بردار طيفى در ابعـاد

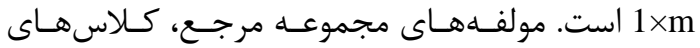

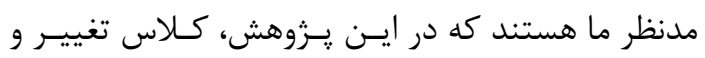

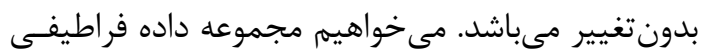

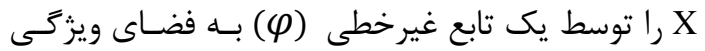

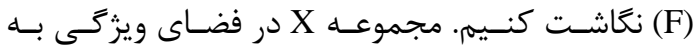

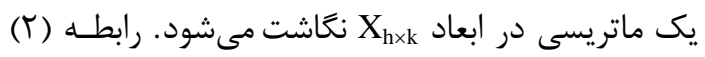

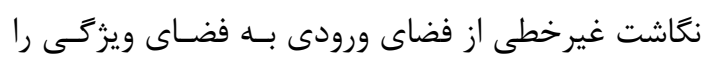

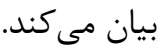


در رابطه (9)،

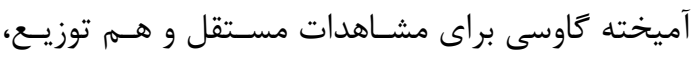

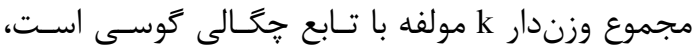
كه مطابق رابطه (V) نمايش داده مىشود. $f\left(x_{i} \mid \mu \cdot \sum\right)=\sum_{i=1}^{k} \alpha_{i} \varphi\left(x_{i} \mid \mu_{i} \cdot \sum_{i}\right) \quad$ (V) در رابطه (V)، (V)

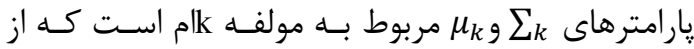

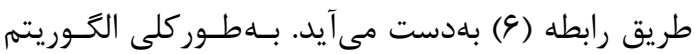

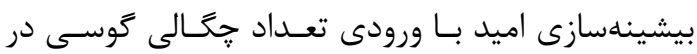

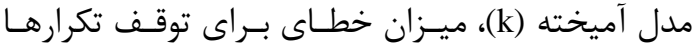

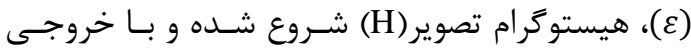

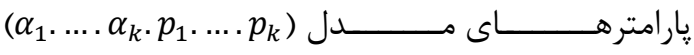

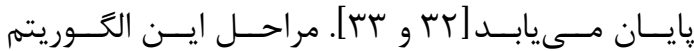

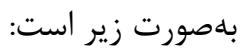

() محاسبه اميد، احتمال تعلق هركدام از مشـاهدات به مؤلفه k ام (رابطه (N)).

$$
\varphi\left(i \mid x_{j}, \theta\right)=\frac{p_{i} f_{i}\left(x_{j} \mid \alpha_{i}\right)}{\sum_{k=1}^{K} p_{k} f_{k}\left(x_{j} \mid \alpha_{k}\right)}
$$

T) بينهازى اميد، در اين مرحله يارامترهاى مدل

آميخته گوسى بلروز رسانى مىشود (رابطه 9.

$$
\text { ) رابطه (9) }
$$

$p_{i}^{\text {new }}=\frac{1}{k} \sum_{j=1}^{k} \varphi\left(i \mid x_{j} \cdot \theta^{\text {old }}\right)$

$\mu_{i}^{\text {new }}=\frac{\sum_{j=1}^{k} x_{j} \varphi\left(i \mid x_{j} \cdot \theta^{\text {old }}\right)}{\sum_{j=1}^{k} \varphi\left(i \mid x_{j} \cdot \theta^{\text {old }}\right)}$

$\sum_{i}^{\text {new }}=\frac{\sum_{j=1}^{k} \varphi\left(i \mid x_{j} \cdot \theta^{\text {old }}\right)\left(x_{j}-\mu_{i}^{\text {new }}\right)\left(x_{j}-\mu_{i}^{\text {new }}\right)^{T}}{\sum_{j=1}^{k} \varphi\left(i \mid x_{j} \cdot \theta^{\text {old }}\right)}$

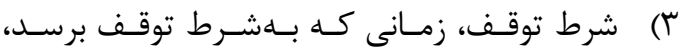
الخوريتم از تكرار خارج مىشود (رابطه (• ()).

$\left\|\theta^{\text {new }}-\theta^{\text {old }}\right\| \leq \varepsilon$

رابطه (·) (1)

براى مورد خاص آشكارسـازى تغييـرات، مـا دو كـلاس

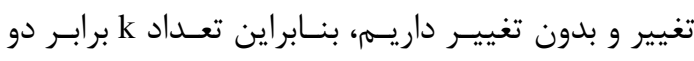

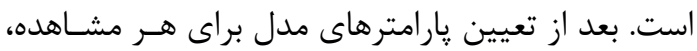

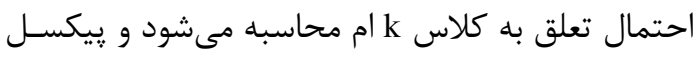

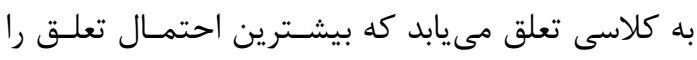

در ايــن رابطـهـ، K تـابع هســته (در ايــن يــروهش از

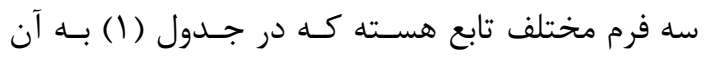
يرداخته شده، اسـتفاده مسىشـود) و نشاندهنده ضرب داخلى بين دو بردار

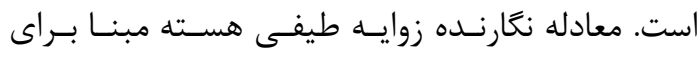

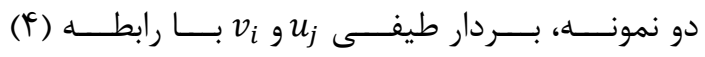
تعريف مىشود.

$\theta_{i j}=\cos ^{-1}\left(\frac{K\left(v_{i} \cdot u_{j}\right)}{K\left(v_{i} \cdot v_{i}\right) \cdot K\left(u_{j} \cdot u_{j}\right)}\right)$ (i) (1)

كـهـ در آن ويزگ تَى است. ץ-F - الخَوريتم بيشينهسازى اميد الكوريتم بيشينهسازى اميد رياضـى يـك روش تكـــارى

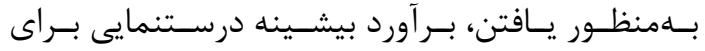
دادهاى گمشده (مشاهدات بلهور كامل موجود نباشد)

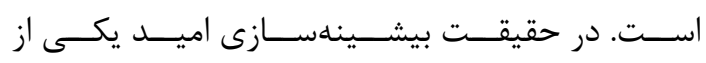
متداولترين روشهايى است كه بهمنظور برآورد جّالى

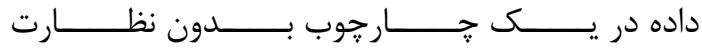

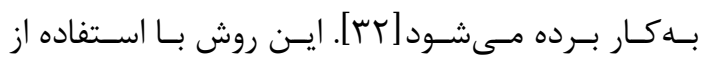
تخمينهاى اوليه از گارامترهاى مدل شـروع شـده و در تكرارهاى بعدى مقادير اين يارامترها بهروز مسىشـوند و

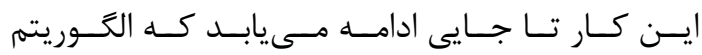

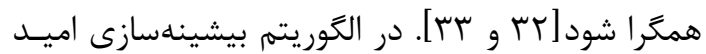
مرحله تكرارى از دو كام محاسبه اميد و بيشـينهسـازى تشكيل مسىشـود. فـرض كنيـد، مـا k مؤلفـهـ در مــل

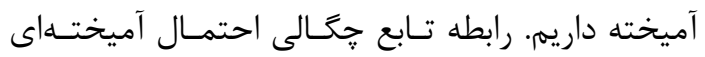
بهصورت رابطه (ه) است [بr و rr].

$$
f(x \mid \theta)=\sum_{i=1}^{k} \alpha_{i} f_{i}\left(x \mid \theta_{i}\right) \quad \text { (ه) }
$$

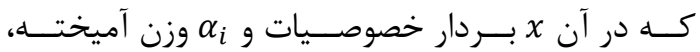

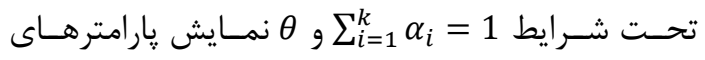
و و $f_{i}\left(\alpha_{1} \ldots \alpha_{k} . \theta_{1} \ldots . \theta_{k}\right)$ شده بلهوسيله $\theta_{i}$ است [بس و سب].

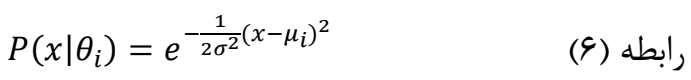


بهدليل اينكه، در الكَوريتم بيشنهسازى اميد، كـلاسهـا برحسب مقادير وييشبينى شده توسط الكوريتم نكارنسـده

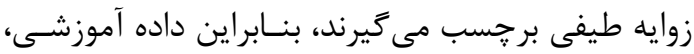

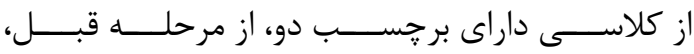
انتخاب مىشود.

علت انتخاب كلاس وسـطى، افـزايش اعتماديـذيرى در

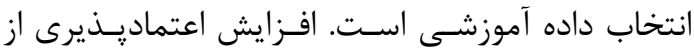
دو عامل نشات مى گيرد: (الف) كلاس نـويز كـهـ معمـولاًا

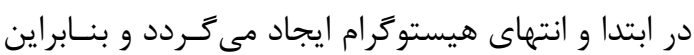
انتخاب كلاس وسطى باعث عدم تاثيريذيرى اين كلاس

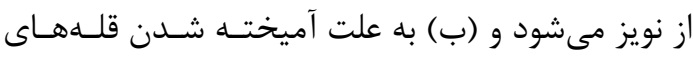
هيستوكرام كلاس تغيير و بدونتغيير انتخاب حدآستانه با دقت پايينى انجام مى گردد. بنـابر اين انتخـاب كـلاس

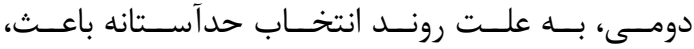

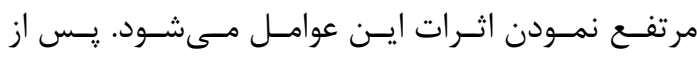
انجام مر احل فوق نمونههاى آموزشى با درصد اطمينـان

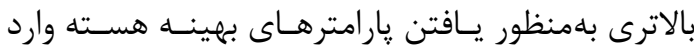

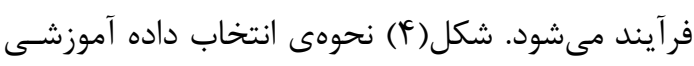
رارائه مى دهد.

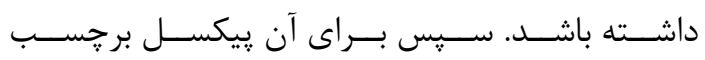
اختصاص داده مىشود[ [r و r بـ]. r-ه - انتخاب داده آموزشى

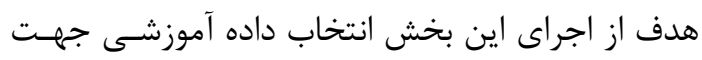

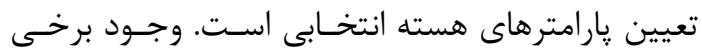

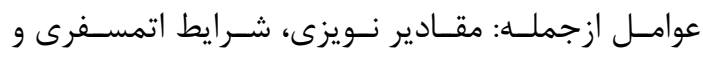

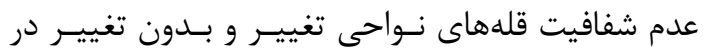

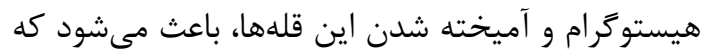

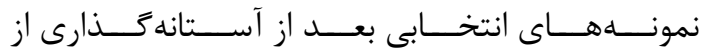

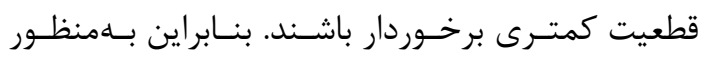

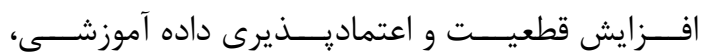
انتخاب داده آموزشى به اساس جهار مرحلـه مسىباشـــ

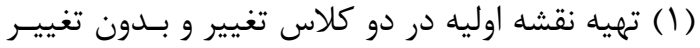

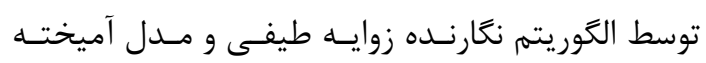
كوسى. (ץ) استخراج ييكسلهاى تغيير و بدون تغيير از

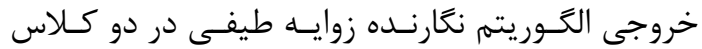

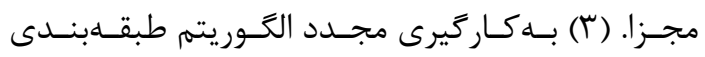

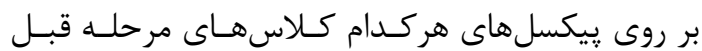

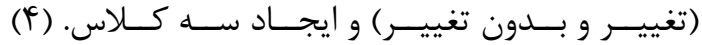

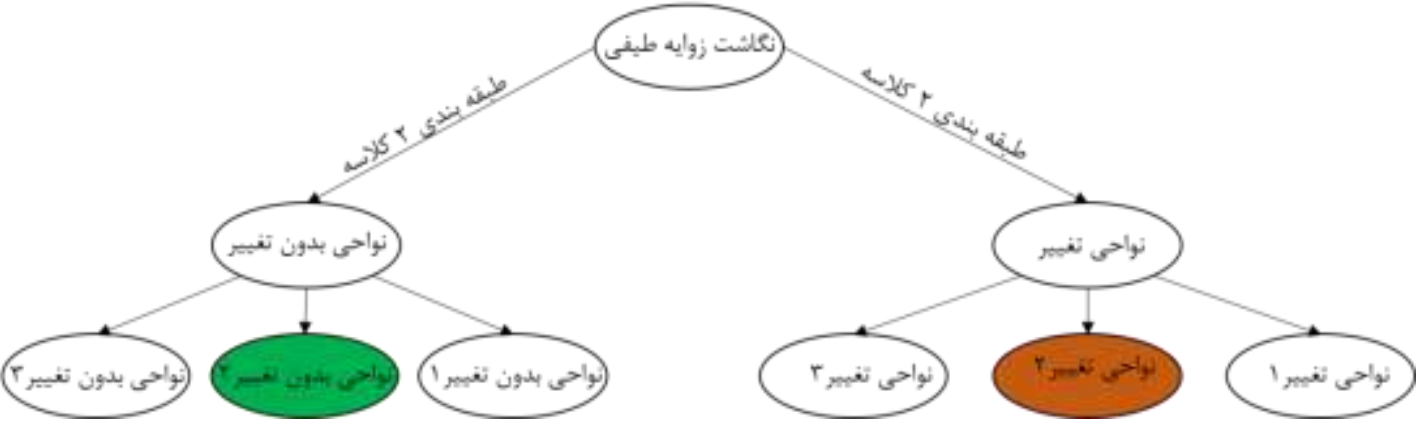

شكل f: نحوهى انتخاب داده آموزشى

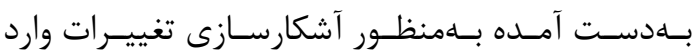
مر حله بعد مىشود.

r- منطقه و داده فراطيفى موردمطالعه ايــن بخــش بــهـ جزئيــات، منطقــهـ مطالعـاتى و داده مورداستفاده بهمنظور آشكارسازى تغييرات در اين مقاله مانه

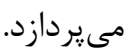

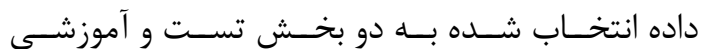
تقسيم مىشوند. در ابتدا توسط الكوريتم جست و جوى شبكهاى يارامترهاى هسته بهينه مىشوند. مقادئه

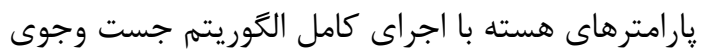

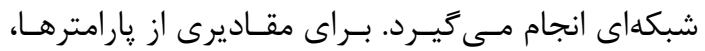

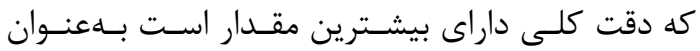

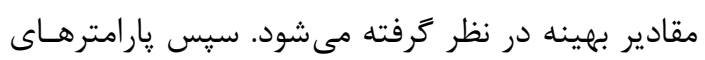




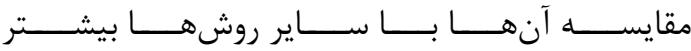

$$
\begin{aligned}
& \text { توضيح داده خواهد شد. }
\end{aligned}
$$

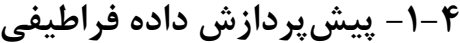

تصاوير فراطيفى اخذشـــه توسـط سـنجنده هـايير يون، به علـت وجـود شـرايط محيطى و دسـتخاهى نيـاز بــهـ يكسرى بيش يردازش دارند. اين پيشيشـردازشهـا در دو

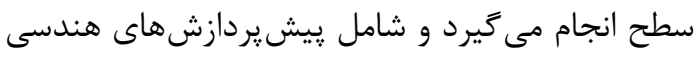
و طيفى است. ييش يردازشهاى طيفى مربوط به مقادير درجه خاكسترى است و شـامل: حـذف جابجـايى يـــ

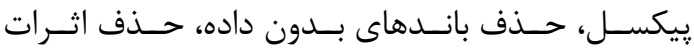

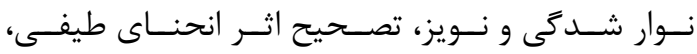
تبديل راديومتريكى، تصحيح اتمسفرى و نرماليزهكردن

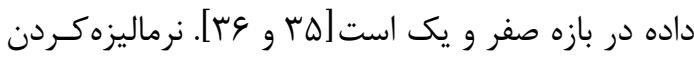
باعث مىشود كه تأثير باندهاى با محدوده عددى بـالاتر بر باندهاى با محدودهى عددى كوجكـتر كمتـر شـــه و

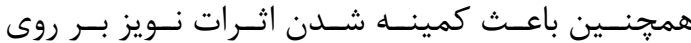

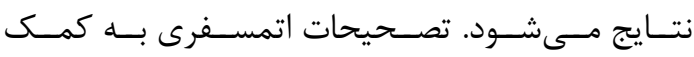

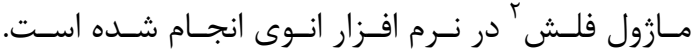

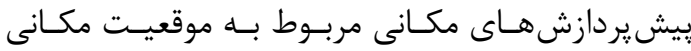
קيكسل ها است، كه براى اين منظور از تصحيح هندسى دئى

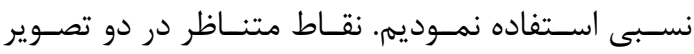
بلهورت دستى شناسايى مىشود و يك تصوير بهعنوان

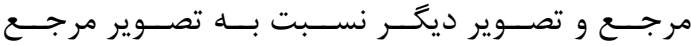
ثبت هندسى مى شود. روش باز نمونهبردارى به كار رفته

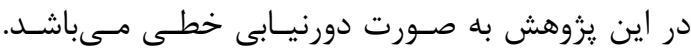

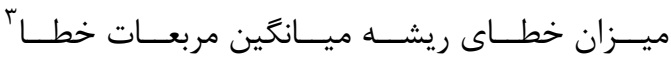
تصحيح هندسى براى دادهاى استفادشده، حدود أر •.

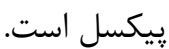

\footnotetext{
${ }^{2}$ FLAASH

${ }^{3}$ Root Mean Square Error
}

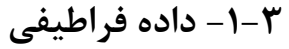

سنجنده هاييريون بروى روى ماهواره 'EO-1 قـرار دارد

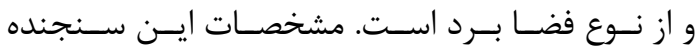
در جدول (r) آمده است.

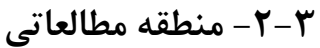

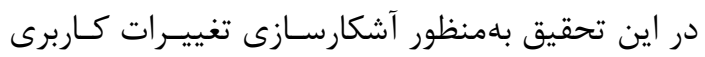
اراضى با استفاده از تصاوير فراطيفى از دادهى مربوط به به بهاديه مزارع كشاورزى استفادهده است. اين دادهها به فاصله

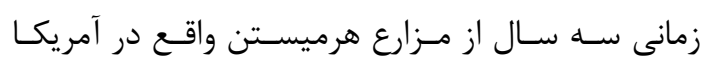

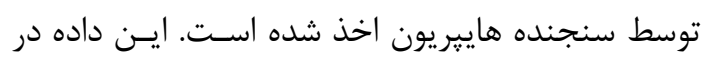

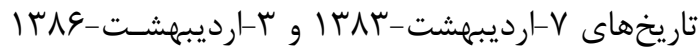

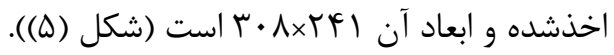
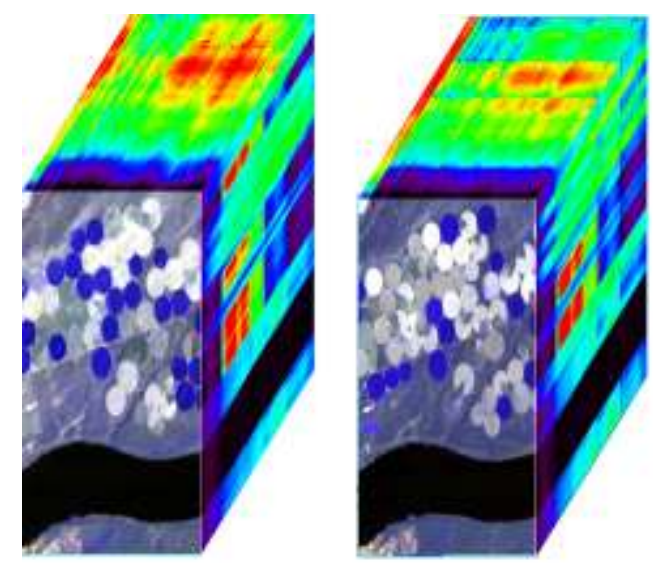

شكل ه: نمايش تركيب رنكَى كاذب داده فراطيفى كه

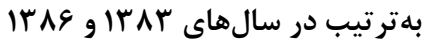
F

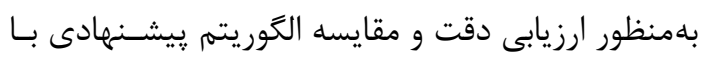

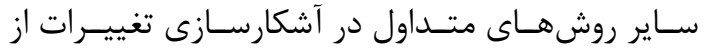

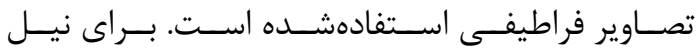
بهاين هدف داده، لازم است يكسرى از يِيش يردازشهـا

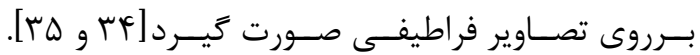

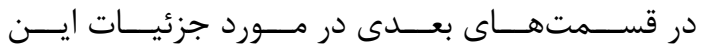

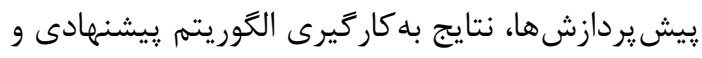

${ }^{1}$ Environment Observation-1 
جدول r: مشخصات سنجنده فراطيفى هاييريون

\begin{tabular}{|c|c|c|c|c|c|}
\hline گَستره طيفى & $\begin{array}{c}\text { توان تفكيك } \\
\text { مكانى }\end{array}$ & يهناى باند & توان تفكيك & توان تفكيك & يوشش طيفى \\
\hline$\mu \mathrm{m} r / \boldsymbol{r}, \boldsymbol{r}$ & • • متر & V V كيلومتر & $1 \cdot \mathrm{nm}$ & عا بيتى & بلهورت ييوسته \\
\hline
\end{tabular}

توسط الكَوريتم اتسو تعيين گَرديد. بـا توجــه بــه نتـايج

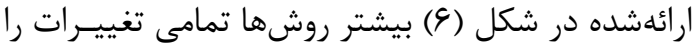

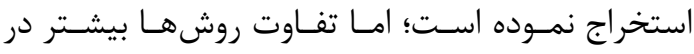

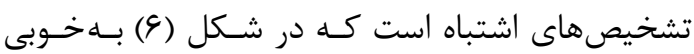
نمايان است. با توجه به خروجى هاى ارائـهشـده در ايسن

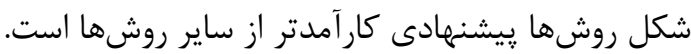
يس از انجام ييشيردازشهاى اشارهشده در قسمتهاى

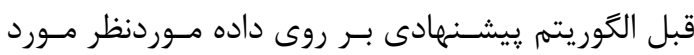

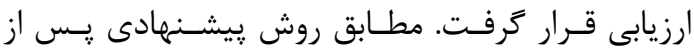

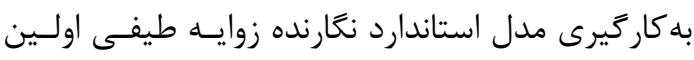

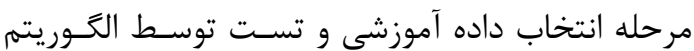
ييشنهادى است. به منظور كـاهش رونــد محاسـباتى از

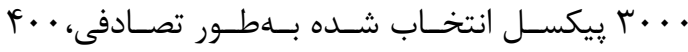

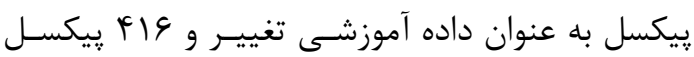

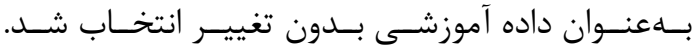
يارامترهاى هسته، بههمراه داده تست توسـط الكَـوريتم جست و جــوى شـــكهاى بهينــه مسىشـود و همجنــين مقادير يارامترهاى هسته در جدول (ب) آمده است.

جدول "ّ: يارامترهاى بهينه هسته

\begin{tabular}{|c|c|c|}
\hline نوع كرنل & يارامتر & مقدار «ارامتر \\
\hline \multirow{3}{*}{ گُندجملهاى } & $d$ & $\Delta$ \\
\hline & $\gamma$ & 1 \\
\hline & $\beta_{0}$ & $1 \cdot^{-\omega}$ \\
\hline يايه شعاعى & $\gamma$ & $1 .^{-9}$ \\
\hline
\end{tabular}

يس از يافتن مقدار بهينه يارامترهاى هسته، دادههــا بــه

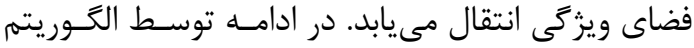

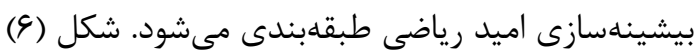

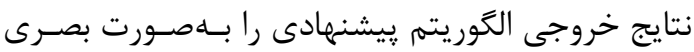

F - بيادهسازى و ارائه نتايج

ارزيابى و ارائـه نتـايج يكىى از مهـممتـرين قسـمتهـاى

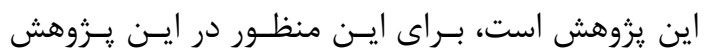

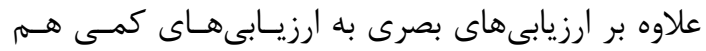
يرداختهشده است. جهت تحليل كمسى از شـاخصهـاى

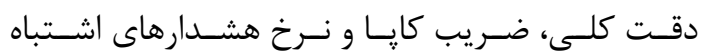

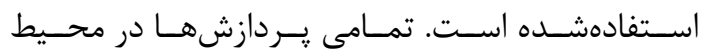
برنامهنويسى ويثروال استوديو سى يـلاس ״ــلاس نسـخه

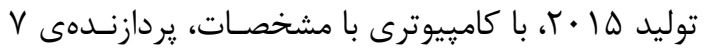

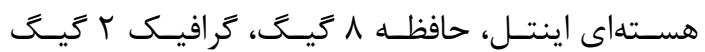

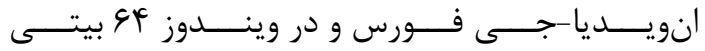

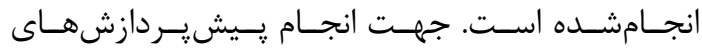
اشارهشده در قسمتهاى قبل از نرمافزار انوى ورزن س.اه استفادهده است. همجنين در اين يزوهش، بـهمنظــور مقايسه روش ييشنهادى از انواع روشهـاى متـدوال در

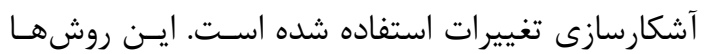

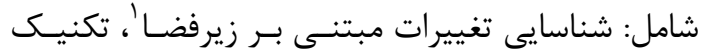

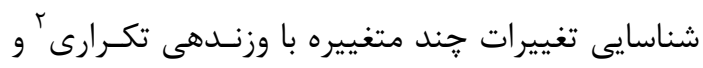

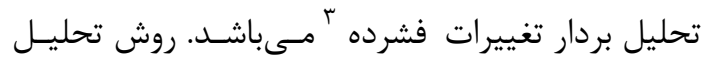
بردار تغييرات فشرده داراى يك يـارامتر تنظـيم اسـت. مقدار يارامتر تنظـيم آن را برابـر 9^^، • قـرار داده شـد.

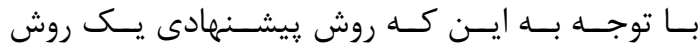

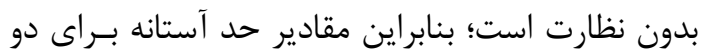

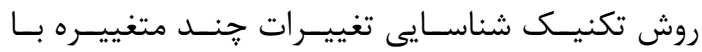
وزندهى تكرارى و شناسايى تغيرات مبتنى بر زيــر فضـا

\footnotetext{
${ }^{1}$ Subspace-based Change Detection

2 Iterative Reweighted Multivariate Alternative Detection

${ }^{3}$ Compressed Change Vector Analysis
} 


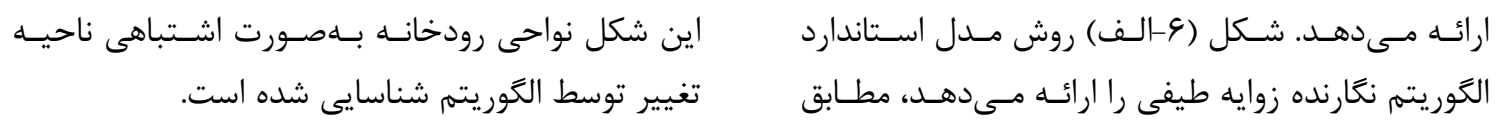

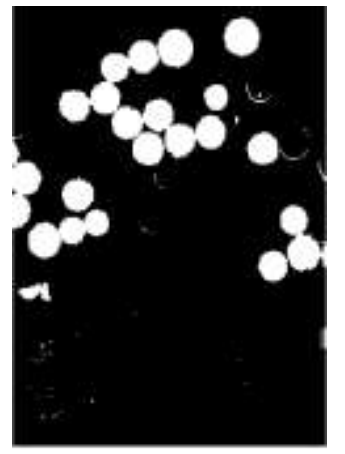

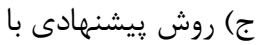

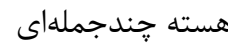

بدون تنيبير

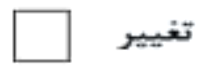

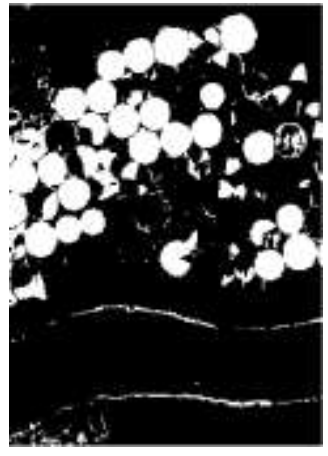

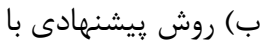

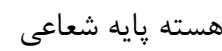

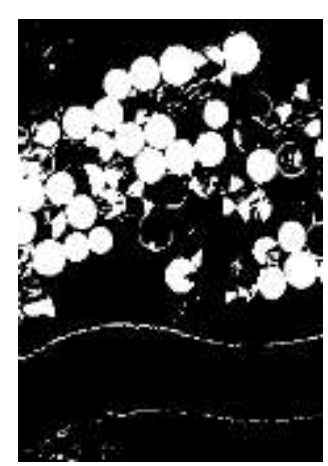

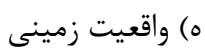

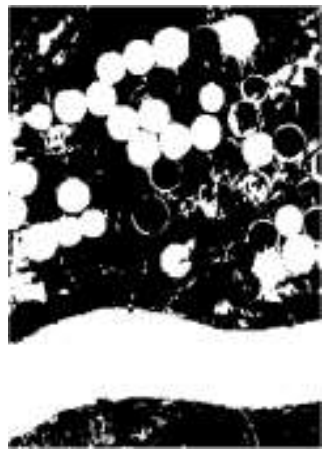

الف) استاندارد نغارنده

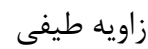

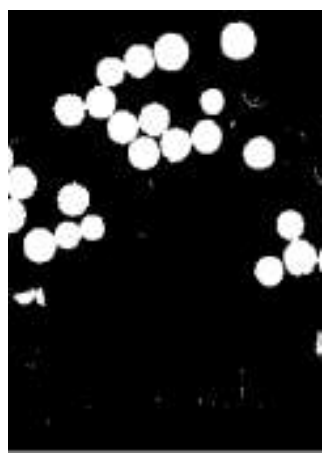

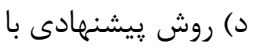

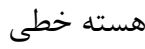

شكل \&: مقايسه بصرى روش يبشنهادى با مدل استاندارد نكارنده زاويه طيفى

الكوريتم بيشنههادى شناسايى شده، فقط تغييرات جزئى اسئ

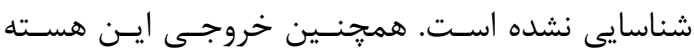

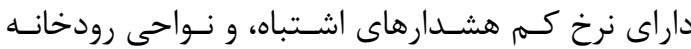
توسط الكوريتم بلهور صحيحى شناسايى شده است.

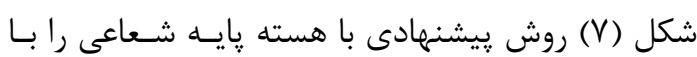

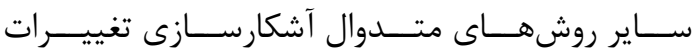
نمايش مى دهد. خروجى نمايش داده شده در اين شكل

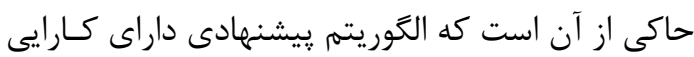
بالايى نسبت به ساير روشهاى متدوال در آشكارسـازى آن آداى تغييرات دارد اين در حالى است كه سـاير الكَـوريتههــا توانايى تشـخيص جزئيـات همـهـ تغييـرات را نداشـتند.
در حاليكـهـ مطـابق شـكل (9-ب-ج-د)، كـهـ در آن از

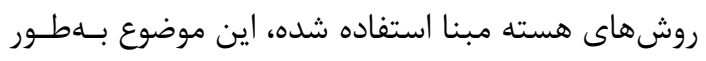

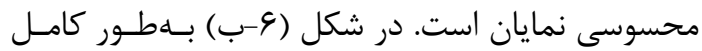

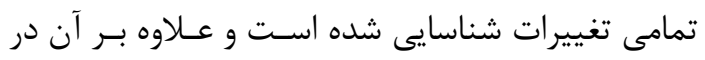

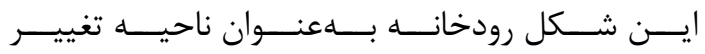
وارد نشده است. اين موضوع نشان دهنده عملكرد بسيار

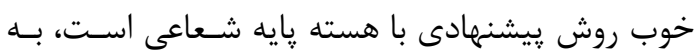

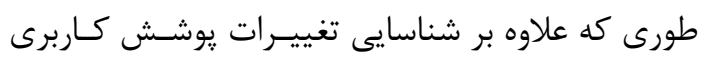

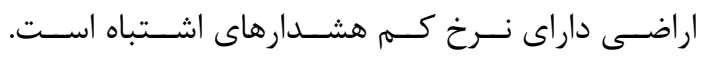

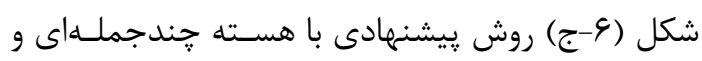

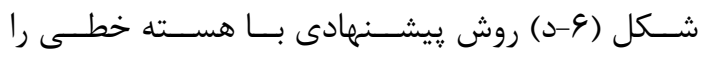

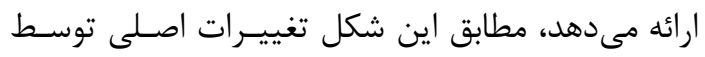




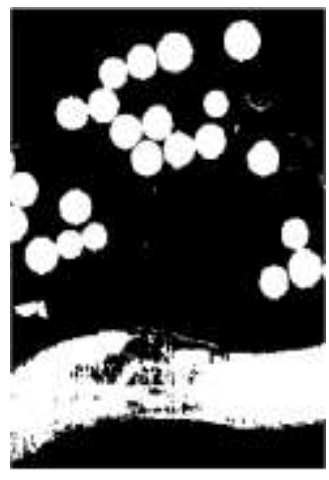

ج) شناسايى تغييرات

مبتنى بر زيرفضا

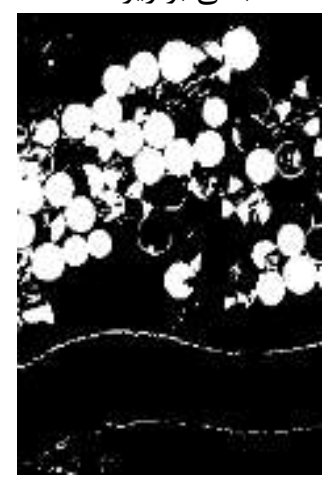

و) واقعيت زمينى

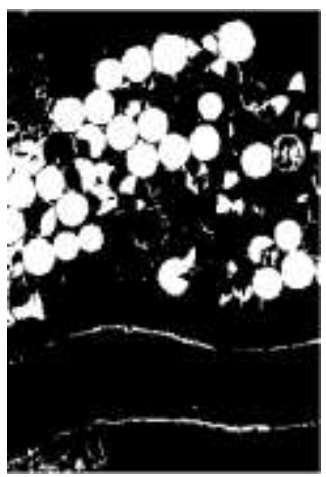

ب) روش ريشنهادى با

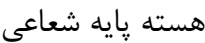

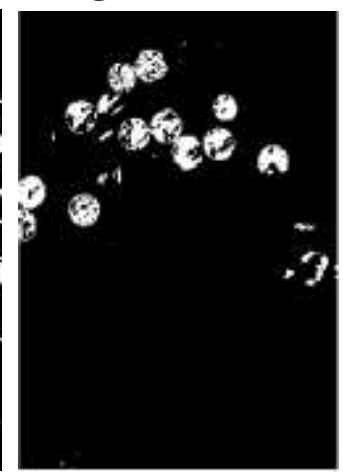

ه) تحليل بردار تغييرات فشرده

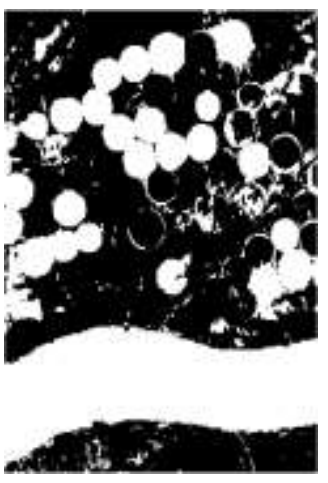

الف)استاندارد نغارنده

زاويه طيفى

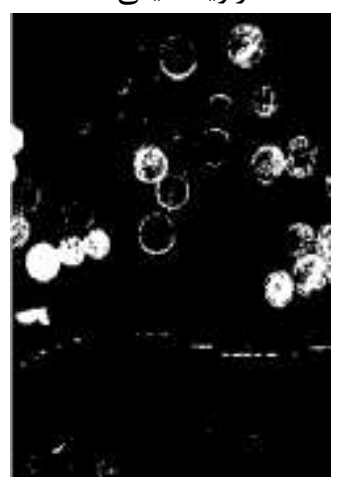

د) تكينيك شناسايى

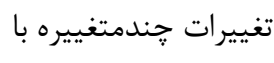

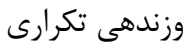

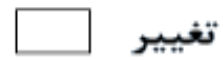

بدوث تغيبير

شكل V: مقايسه بصرى روش پيشنههادى با ديگر روش هاى متداول آشكارسازى تغييرات

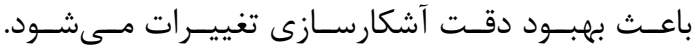

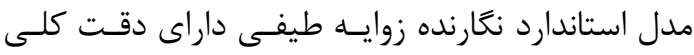

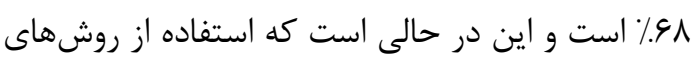

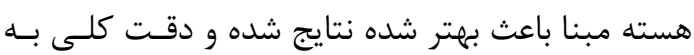

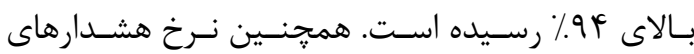

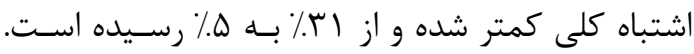
هردوى تحليل بصرى و كمى نشاندهنده عملكرد بسيار

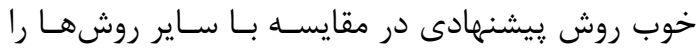
نشان مى دهد.
بـهمنظظـور اثبـات كــارايى روش ييشــنهادى و تحليـل

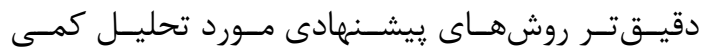

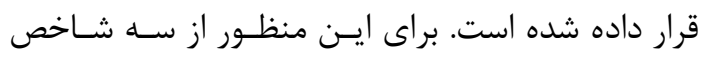

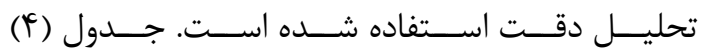

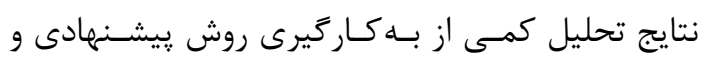

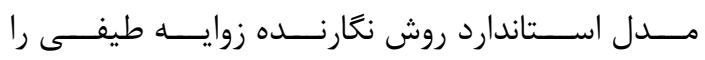

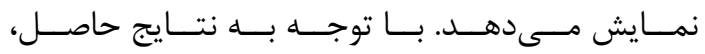

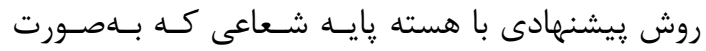
برجسته نمايان شده، داراى دقت بالايى نسبت به سـاير روشها است. همجنين استفاده از روشهاى هسته مبنا 


\begin{tabular}{|c|c|c|c|}
\hline نرخ هشدار & شاخص & كلى دق & روش آشكارسازى تغييرات \\
\hline$r \mid, q 1$ & $\cdot, r \cdot q$ & 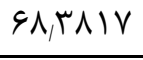 & نغارنده زوايه طيفى استاندارد \\
\hline$\Delta, \Delta V$ & •|^rq| & $q f, p \| l$ & روش پيشنهادى با هسته يايه شعاعى \\
\hline $1 \cdot 114$ &., 99. & $\wedge \vee / \wedge \wedge q$ & روش پيشنهادى با هسته جُندجملهاى \\
\hline $1 \cdot, \pi 9$ & $\cdot \varepsilon \Delta F$ & $\wedge q, \vee{ }^{\prime} \Delta$ & روش پيشنهرادى با هسته خطى \\
\hline$|9 /| \mathrm{FV}$ & $\cdot r \cdot r$ & $\Lambda r_{,} \wedge \Delta r^{\prime}$ & شناسايى تغيرات جند متغييره با وزندهى تكرارى \\
\hline $10, F T$ & $\cdot 1919$ & $\Delta F / \Delta \vee \Delta$ & تحليل بردار تغييرات فشرده \\
\hline$r T, I F \Delta$ & $\cdot, 1, \ldots$ & $\vee \vee \wedge \Delta \Delta$ & شناسايى تغييرات مبتنى بر زيرفضا \\
\hline
\end{tabular}

جالشهاى موجود در اين يـرزوهش يـك روش خودكـار آشكارسازى تغييرات به كمك تصاوير فراطيفى ارائه شد

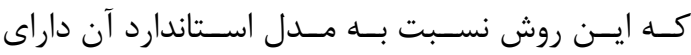

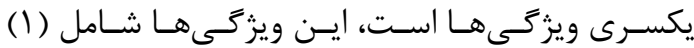
خودكار بودن و عدم نيـاز بـه هركونسه داده آموزشسى از سوى كاربر، (r) يتانسيل و دقت بالاى روش بيشنهاد در كشف تغييرات بهطورى كه قابليت تشخيص تغييرات

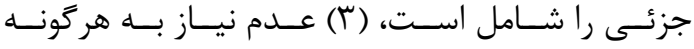

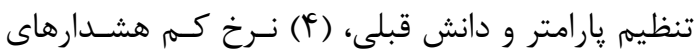

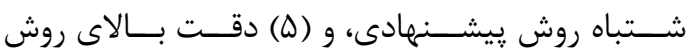

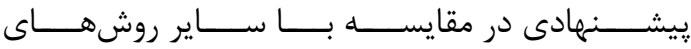

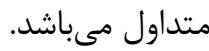

[1] A. R. John and J. Xiuping, "Remote Sensing Digital Image Analysis," N. Y. SpringerVerl. Berl. Heidelb., p. 55, 2006.

[2] H. Grahn and P. Geladi, Techniques and applications of hyperspectral image analysis. John Wiley \& Sons, 2007.

[3] D. Landgrebe, "Hyperspectral image data analysis," IEEE Signal Process. Mag., vol. 19, no. 1, pp. 17-28, 2002.

[4] M. T. Eismann, "Hyperspectral remote sensing," 2012.

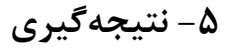

زمين همواره تحت تأثير يكسرى از فعاليتهاى طبيعى و مصنوعى دستخوش يكســـى از تغييـرات مسىشـود. بلمنظور مديريت بهينه استفاده از منابع و جلـوكيرى از از

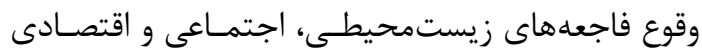
آكاهى از اين تغييرات امرى ضرورى است كه اين امر با

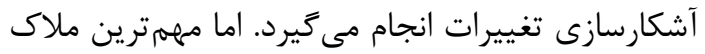

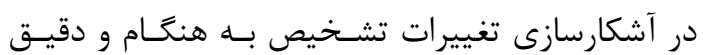
اين تغييرات است. استفاده از روشهاى هستــاته مبنـا در

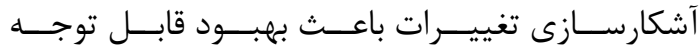

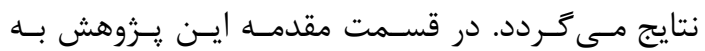
جالشهاى موجود در آشكارسازى تغييـرات بـا تصـاوير

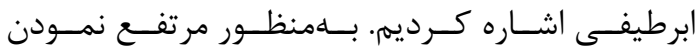

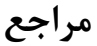

[5] R. B. Smith, "Introduction to hyperspectral imaging," Microimages Retrieved June, vol. 30, p. 2008, 2006.

[6] A. Singh, "Review article digital change detection techniques using remotely-sensed data," Int. J. Remote Sens., vol. 10, no. 6, pp. 989-1003, 1989.

[7] P. R. Coppin and M. E. Bauer, "Digital change detection in forest ecosystems with remote sensing imagery," Remote Sens. Rev., vol. 13, no. 3-4, pp. 207-234, 1996. 
[8] M. Goswami and M. V. Khire, "Land Use and Land Cover Change Detection for Urban Sprawl Analysis of Ahmedabad City using Multitemporal Landsat Data,” Int. J. Adv. Remote Sens. GIS, p. pp-1670, 2016.

[9] L. Ma et al., “Object-Based Change Detection in Urban Areas: The Effects of Segmentation Strategy, Scale, and Feature Space on Unsupervised Methods," Remote Sens., vol. 8, no. 9, p. 761, 2016.

[10]S. Touati, M. Naylor, and I. Main, "Detection of change points in underlying earthquake rates, with application to global mega-earthquakes," Geophys. J. Int., vol. 204, no. 2, pp. 753-767, 2016.

[11]X. Chen, L. Vierling, and D. Deering, "A simple and effective radiometric correction method to improve landscape change detection across sensors and across time," Remote Sens. Environ., vol. 98, no. 1, pp. 63-79, 2005.

[12] M. Hussain, D. Chen, A. Cheng, H. Wei, and D. Stanley, "Change detection from remotely sensed images: From pixel-based to object-based approaches," ISPRS J. Photogramm. Remote Sens., vol. 80, pp. 91106, 2013.

[13] R. Garrard, T. Kohler, M. F. Price, A. C. Byers, A. R. Sherpa, and G. R. Maharjan, "Land Use and Land Cover Change in Sagarmatha National Park, a World Heritage Site in the Himalayas of Eastern Nepal," Mt. Res. Dev., vol. 36, no. 3, pp. 299-310, 2016.

[14]G. Gutman and V. Radeloff, Land-Cover and Land-Use Changes in Eastern Europe after the Collapse of the Soviet Union in 1991. Springer, 2016.

[15]A. Popp et al., "Land-use futures in the shared socio-economic pathways," Glob. Environ. Change, 2016.

[16]K. Saez de Bikuña, M. Z. Hauschild, K. Pilegaard, and A. Ibrom, "Environmental performance of gasified willow from different lands including land-use changes," GCB Bioenergy, 2016.

[17]E. Ustaoglu, C. P. Castillo, C. Jacobs-
Crisioni, and C. Lavalle, "Economic evaluation of agricultural land to assess land use changes," Land Use Policy, vol. 56, pp. 125-146, 2016.

[18]F. Bovolo, S. Marchesi, and L. Bruzzone, "A framework for automatic and unsupervised detection of multiple changes in multitemporal images," IEEE Trans. Geosci. Remote Sens., vol. 50, no. 6, pp. 2196-2212, 2012.

[19]C. Wu, L. Zhang, and B. Du, "Targeted change detection for stacked multi-temporal hyperspectral image," in Hyperspectral Image and Signal Processing (WHISPERS), 2012 4th Workshop on, 2012, pp. 1-4.

[20] C. Wu, B. Du, and L. Zhang, "A subspacebased change detection method for hyperspectral images," IEEE J. Sel. Top. Appl. Earth Obs. Remote Sens., vol. 6, no. 2, pp. 815-830, 2013.

[21] Y. Yuan, H. Lv, and X. Lu, "Semisupervised change detection method for multi-temporal hyperspectral images," Neurocomputing, vol. 148, pp. 363-375, 2015.

[22] A. Ertürk and A. Plaza, "Informative change detection by unmixing for hyperspectral images," IEEE Geosci. Remote Sens. Lett., vol. 12, no. 6, pp. 1252-1256, 2015.

[23] S. Liu, L. Bruzzone, F. Bovolo, and P. Du, "Unsupervised multitemporal spectral unmixing for detecting multiple changes in hyperspectral images," IEEE Trans. Geosci. Remote Sens., vol. 54, no. 5, pp. 2733-2748, 2016.

[24]R. Shah-Hosseini, S. Homayouni, and A. Safari, "A hybrid kernel-based change detection method for remotely sensed data in a similarity space," Remote Sens., vol. 7, no. 10, pp. 12829-12858, 2015.

[25] G. Camps-Valls, "A Note on the Kernel Spectral Angle Mapper," Electron. Lett., 2016.

[26]X. Liu and C. Yang, "A kernel spectral angle mapper algorithm for remote sensing image classification," in Image and Signal 
Processing (CISP), 2013 6th International Congress on, 2013, vol. 2, pp. 814-818.

[27] A. Chen, H. Zhao, and Z. Pei, "Is Time Series Smoothing Function Necessary for Crop Mapping?-Evidence from Spectral Angle Mapper After Empirical Analysis," in Computer and Computing Technologies in Agriculture IX: 9th IFIP WG 5.14 International Conference, CCTA 2015, Beijing, China, September 27-30, 2015, Revised Selected Papers, Part I, 2016, pp. 335-347.

[28]E. Hasan, T. Fagin, Z. El Alfy, and Y. Hong, "Spectral Angle Mapper and aeromagnetic data integration for gold-associated alteration zone mapping: a case study for the Central Eastern Desert Egypt," Int. J. Remote Sens., vol. 37, no. 8, pp. 1762-1776, 2016.

[29] H. Zhuang, K. Deng, H. Fan, and M. Yu, "Strategies Combining Spectral Angle Mapper and Change Vector Analysis to Unsupervised Change Detection in Multispectral Images," IEEE Geosci. Remote Sens. Lett., vol. 13, no. 5, pp. 681685, 2016.

[30] G. Camps-Valls, L. Bruzzone, and others, Kernel methods for remote sensing data analysis, vol. 2. Wiley Online Library, 2009.

[31]M. Fauvel, J. Chanussot, and J. A. Benediktsson, "Evaluation of kernels for multiclass classification of hyperspectral remote sensing data," in 2006 IEEE International Conference on Acoustics Speech and Signal Processing Proceedings, 2006, vol. 2, pp. II-II.

[32]M. Fauvel, J. Chanussot, and J. A. Benediktsson, "A spatial-spectral kernelbased approach for the classification of remote-sensing images," Pattern Recognit., vol. 45, no. 1, pp. 381-392, 2012.

[33]M. A. Mahjoub and others, "Image segmentation by adaptive distance based on EM algorithm,” ArXiv Prepr. ArXiv12041629, 2012.

[34]B. Datt, T. R. McVicar, T. G. Van Niel, D.
L. Jupp, and J. S. Pearlman, "Preprocessing EO-1 Hyperion hyperspectral data to support the application of agricultural indexes," IEEE Trans. Geosci. Remote Sens., vol. 41, no. 6, pp. 1246-1259, 2003.

[35]D. Scheffler and P. Karrasch, "Preprocessing of hyperspectral images: A comparative study of destriping algorithms for EO1-Hyperion," in SPIE Remote Sensing, 2013, p. 88920H-88920H.

[36] H. Li, D. Zhang, Y. Zhang, and Y. Xu, "Research of image preprocessing methods for EO-1 Hyperion hyperspectral data in tidal flat area," Geoinformatics, p. $71471 \mathrm{G}-$ $71471 \mathrm{G}, 2008$. 


\title{
Improving Land Cover Change Detection using Kernel Spectral Angle Mapper Approach in Hyperspectral Images
}

\author{
Mehdi Hasanlou $^{* 1}$, Seyed Teimoor Seydi ${ }^{2}$, Abdoreza Seydi $^{3}$
}

1- Assistant professor in School of Surveying and Geospatial Engineering, College of Engineering, University of Tehran

2- Ms.c student of Remote Sensing in School of Surveying and Geospatial Engineering, College of Engineering, University of Tehran

3- Ms.c of Computer Science in University PayamNoor Gorgan

\begin{abstract}
Increasing the population and urban development is one of the most important human actions that cause changes on the face of the earth, especially in the developing countries, which is more. This process can cause devastating effects such as social, economic and biophysical. The harmful effects include; loss of agriculture lands, pasture and forest, change the pattern of the water, which somehow is associated with the changing patterns of land use and land cover. Land use and land cover changes as a basic factor in the changes of the Environment Act and converted into crisis. Identifying and evaluating the potential land-use patterns is essential, that if done on timely and with the high precision, it can help the planners and managers of relevant organizations for more conscious decision and making optimum use of resources in order to prevent the crisis. That would only be possible with the change detection. The hyperspectral images, due to having high spectral resolution, improved results of changes detection, provide more details of the changes. The main purpose of this research is to improve the process of land-use changes detection using spectral angle mapper algorithm, expectation maximization based on kernel based with hyperspectral imagery. The most important advantage of this method are as follow: unsupervised, no need to setting parameters of the knowledge basis, high precision and low false alarms rate. To evaluate the ability of the proposed method, hyperspectral imagery received from agricultural fields of Hermiston in the United States that captured by Hyperion sensors were used. The results are a significant improvement with the use of the proposed method for change detection in the standard spectral angle-mapping model compared to the top so that the overall accuracy is $94 \%$, the coefficient Kappa 0.84 and false alarm rates of less than $6 \%$.
\end{abstract}

Key words:. Change Detection, Spectral Angle Mapper, Kernel Based, Hyperspectral Images, Expectation-Maximization Segmentation, Land Cover. Logistic Regression

Correspondence Address: School of Surveying and Geospatial Engineering, College of Engineering, University of Tehran, Tehran, Iran. Tel: +982161114525

Email : hasanlou@ut.ac.ir 